\title{
Role of Employee Satisfaction in Influencing Patient Satisfaction
}

${ }^{1}$ Shibu John, ${ }^{2}$ Rasika Sharma, ${ }^{3}$ Manoj Kumar Dhingra

\begin{abstract}
The proposed study is an attempt to understand the link between Outpatient Department (OPD) patient satisfaction and job satisfaction among front office executives of the OPD. The study was conducted in a 300 bedded multispecialty hospital in Delhi. The study is very important as the OPD is considered to be the mirror of any hospital, which reflects the functioning of the hospital being the first point of contact between the patient and the hospital staff. A structured questionnaire was used in conducting the study. Total 158 patients were interviewed during 2 months period. Stratified random sampling technique used in selecting the samples. Both type of patients, first timers and old patient participated in the study. As second part of the study, all 22 front office executives from the above-mentioned three concerned departments were participated. The age group of the employees ranged from 20 to 50 years.
\end{abstract}

Keywords: OPD, Front office, Patient satisfaction, Employee satisfaction, Third party administrator.

How to cite this article: John S, Sharma R, Dhingra MK. Role of Employee Satisfaction in Influencing Patient Satisfaction. Int J Res Foundation Hosp Healthc Adm 2013;1(1):13-18.

Source of support: Nil

Conflict of interest: None

\section{INTRODUCTION}

It has been quite evident that organizations with a good working environment have better leverage to achieve customer satisfaction; at the same time it also proven that a specific key influencing factor of achieving customer satisfaction is employee satisfaction. There is a 'positive and high significant correlation between customer satisfaction and employee satisfaction'. Employee satisfaction is greatly related to service quality and to customer satisfaction. The proposed study is an attempt to understand the link between customer satisfaction and employee satisfaction between front office executives of the outpatient department (OPD) of a multispecialty hospital.

\footnotetext{
${ }^{1}$ Associate Professor, ${ }^{2}$ Student, ${ }^{3}$ Former Associate Professor

1,2 Department of Management, Jamia Hamdard, Hamdard Nagar, New Delhi, India

${ }^{3}$ Department of Hospital Administration, Institute of Clinical Research India, New Delhi, India

Corresponding Author: Shibu John, Associate Professor Department of Management, FMIT, Jamia Hamdard, Hamdard Nagar, New Delhi-110075, India, Phone: 91-9873668705, e-mail: shibu.john14@gmail.com
}

OPD services are one of the important functions of any hospital. It is the mirror of the hospital, which reflects the functioning of the hospital being the first point of contact between the patient and the hospital staff. Most of the corporate hospitals put lot of emphasize on delivering good care at the OPD services. Quality of services at various points in OPD is the prime concern of the management. One of the areas in OPD is front office or reception. According to the sections and services, the hospital may have multiple reception areas. The employees at reception are very busy in handling patient queries, registration appointments, counseling, cash collection, etc. Therefore, the employee satisfaction is one of the main variables in delivering quality services.

Healthcare employees' satisfaction have been found to have several impacts on the quality of care delivered which ultimately influences the level of patient satisfaction. Employee dissatisfaction negatively impacts the quality of care and ultimately has an adverse effect on patient loyalty and in turn hospital profitability. Quality improvement initiatives were shown to have a positive correlation with employee satisfaction. Healthcare employee moral also demonstrates a strong correlation with patient satisfaction scores, showing that the lack of commitment and engagement have far-reaching impacts on more than just employee turnover. Employee satisfaction also appears to have a strong relationship with the quality of care delivered and related costs. When employees are more satisfied it helps reduce stress, turnover, leaves of absence, and lower work-related disability and violence claims. Satisfied employees also were found to lead to shortened lengths of stay for patients and lower variable costs. The reductions in recruitment and retention costs and fewer employees missing work combined with lower patient variable costs and mistakes make improving employee satisfaction more appealing to administrators. By focusing on improving the quality of care, healthcare organizations can not only improve patient satisfaction, but also improve employee satisfaction and loyalty to the organization. This in turn will further impact the quality of care because of the interrelationship of this chain.

If changes can be implemented in one department with success, then the same changes can be attempted in other 
departments that may be experiencing the same issue of low customer satisfaction and low employee satisfaction. It is also possible that if department $\mathrm{X}$, a large patient care department, is able to increase their customer satisfaction scores, the hospital mean satisfaction score will also rise. Completing this study will not only increase the awareness of how employee satisfaction impacts customer satisfaction, but it will also create a path to happier, more effective employees.

\section{LITERATURE REVIEW}

There have been many studies done to understand the role of employee satisfaction on customer satisfaction. 'The Press Ganey Satisfaction Report (2003)', described that health-care system has done a good job that many patients take the technical aspects of their care for granted. But they are sensitive to how they are treated a persons, not merely as bodies. This means that hospitals need to foster a culture of responsiveness to patients. Staff should attend to the concerns of every patient, and understand that these concerns include emotional and spiritual, as well as physical issues. ${ }^{1}$ This is the essence of customer service in the healthcare arena. This particular type of customer, a patient, expects the equipment to be current and treatments to be effective in all healthcare institutions. The variable among healthcare organizations is how the patient is treated. Customers are scrutinizing 'the how' of service provision, not just 'the what' of service. If a customer is satisfied with the way the product is delivered, a positive relationship will develop between the consumer and the provider. This is especially evident when consistency in the provision of services is attained. The customer will return for the cares that they perceive as high quality and the institution will have profitability. ${ }^{2}$ One of the major issues healthcare providers deal with, when considering customer service are the ideals that defines it. Health Care's Management, Myopia states that the healthcare industry has three concepts that paint its identity. These are: thinking of itself as a thing rather than a place, the patient experience is managed only within facility walls, and the business is defined by diagnoses and treatments of diseases rather than as health management. These ideals are important to note when asking for feedback from the customer's viewpoint. Patients often begin, evaluating the healthcare experience even before they enter through the doors. There are certain expectations initiated by the first phone call or from a previous encounter with an institution. The evaluation by the customer continues through the healthcare event and ends with the recovery period. It is vital to capture all aspects of the customer experience with any survey tool chosen by an organization. ${ }^{3}$
Overall, most customers of the healthcare industry, patients, will be satisfied or very satisfied with their experiences. $85 \%$ of patients in average hospitals rank care as good or very good. Hospital executives have the challenge of encouraging staff not to become content with these good ratings. Healthcare providers can become preoccupied with those customers who have a poor experience with the facility and give low ratings. The real challenge is to increase the overall satisfaction scores by having more patients experience a very good occurrence rather than simply a good one. ${ }^{4}$

When hospital staff does a good job according to their job description, but without warmth or sincerity, then patients will likely rate their satisfaction as 'fair' or 'average'. If the employees add some sensitivity and courtesy, the experience rating can increase to a 'good' or 'satisfied'. But add some touches that exceed the expectations of what the patient had for their care, the rating of satisfaction will reach the 'very good' or 'excellent' mark.

It is important to realize that one bad experience can flavor the future encounters with the healthcare facility. It is also noteworthy to recognize that one individual employee can influence the outcome of an entire customer experience. It is unrealistic to believe that department managers can supervise all employees all the time to determine if they are treating customers in an acceptable manner. It is important to manage customer service activities through a facility's culture of providing exceptional customer service when delivering the procedures or treatments. ${ }^{6}$ With a customer service culture, service encounters are managed by all staff. Employees are vested in customer service concepts from the hiring process through the annual evaluation of observed service practices. This concept makes all employees responsible and managers of 'very good' experiences.

Employees are curious on what other employees saw as both strengths of the organization as well as areas that need improvement. Other useful information includes how the particular department compares to other departments in the same organization as well as against national benchmarks. ${ }^{1}$ Action plans also need to be aligned to the strategic need of the entire company. ${ }^{7}$ The managers are again encouraged to involve their employees. Here is an opportunity for employees to become engaged in the process improvements that need to occur and understand their personal roll. ${ }^{1}$ Employees can become disconnected from their jobs, because of never ending changes and challenges to perform better. ${ }^{8}$ Involving the employees at the beginning of the planning process, keeps them focused on the positive aspects that change can bring to their job. Empowering employees allows them to think for themselves, encourages creativity, and produces more efficient workers. ${ }^{9}$ Because the employees have been part of developing or improving 
a process, they will have ownership and seek to see their suggestions succeed. Employees, who are not empowered, tend to be more apathetic toward their job and seem to just go through the motions without any interest in performing better. The involvement of employees in not only the feedback process, but also the strategic planning process can only bring about workable plans that can be implemented at the department level and possibly at the hospital wide level. ${ }^{1}$

Definition of empowered employees-'It is seeing the gifts and the talents, the caring and the intelligence in another person and helping them live up to that'. ${ }^{10}$ Managers of healthcare departments need to see the potential in their employees to provide accurate, timely care to patients with the flair of customer service. This will tie the employee to the customer who will be satisfied with the facility.

As discussed earlier in the section on customer satisfaction, there is an issue on how healthcare identifies itself. Many healthcare facilities focus efforts in relaying to customers how modern their equipment is or how safe their procedures are. When looking at the satisfaction of healthcare customers, they expect all institutions to have modem equipment and safe practices. The difference is how the front line care providers connect with the person and show understanding and empathy as they administer the cares. ${ }^{1}$ Another useful information may be the attrition rate or churn rate or employee moves. While a zero percent attrition rate may be ideal, but it is not likely. ${ }^{11}$ As Bernadette Kenny reports in 'Forbes' magazine, any rate below 15 percent annually is considered healthy and no cause for alarm. This means that a company of 200 workers can lose 30 individuals within a calendar year without it becoming a problem. ${ }^{12}$ Human Resource Departments have struggled in the past on how to relate the 'people expense' to the bottom line. It is through customer service provided by the employees that will cause a patient to return and subsequently bring in revenue. ${ }^{13}$

Healthcare has struggled with this concept as, historically, customers of healthcare have 'needed' those services provided by healthcare institutions. Choices were not available and consumers had blind faith that all healthcare facilities would provide them what they needed. Now with competition for customers and more educated customers, the service side has become more important than just the accessibility of healthcare systems. Employee satisfaction is especially high in service organizations that not only deliver high value to customers but do it through frontline service workers who are carefully selected, well-trained, given latitude to solve customer problems, compensated at least in part on their performance, and even given responsibility for ensuring that their positions are staffed. ${ }^{2}$

The above studies show the results from the literature review of the relationship between employee satisfaction and patient satisfaction.

\section{METHODOLOGY}

\section{Objective}

The objective of the study is to identify the level and factors responsible for patient satisfaction with respect to their experience at front office. The study also examines the relationship between front office employee's job satisfaction and patient satisfaction.

\section{Research Design}

Descriptive and analytical research designs were used to conduct the study. Employees were interviewed according to a structured questionnaire, where both patient and employee satisfaction questions were included. Another questionnaire was used to identify the patient satisfaction level. Many activities like patient traffic control, front office staff absenteeism, patients quarrel were also observed during the study period.

\section{Tool Used}

A structured questionnaire was used in conducting the study. The questionnaire for employees consisted of employee details and a total of 19 questions out of which 14 were close ended and rest 5 were open ended. On the other hand, questionnaire for patients consisted of patient details and a total of 12 questions out of which 11 were close ended and one was open ended.

\section{Sample Size}

Total 158 patients were interviewed during 2 months period. Stratified random sampling technique used in selecting the samples. Both type of patients, first timers and old patient participated in the study. Three types of patients participated in the study, i.e. cash patients, international patients and TPA/corporate patients.

As second part of the study, all 22 employees from the concerned departments were participated. The age group of the employees ranged from 20 to 50 years. The supervisors of the departments were also interviewed. The staff interviewed consisted of 22 employees having largest population of executives (40.9\%) and assistants (36.4\%) mostly from the registration department (36.4\%). 59.1\% of staff interviewed were males. Out of the total employees participated in the study, mostly were from the age group of 20 to 25 years $(40.9 \%)$.

\section{Sample Background}

Out of total patients participated in the study, majority belonged to the age group of 20 to 40 years $(63.9 \%)$. The 
sample population showed greater percentage of males $(63.3 \%)$ than females $(36.7 \%)$. $61.4 \%$ of the population was from Delhi itself. Most of the interviewed patients were graduates $(51.9 \%)$. Out of 19 specialities in the hospital, maximum patients interviewed were of medicine (24.7\%).

\section{Data Analysis}

As specified above, the data were collected from three different types of front offices, i.e. TPA help desk, Main registration and international patient's desk. Data collected with the help of questionnaires was analyzed using SPSS software package and results were interpreted.

\section{FINDINGS}

It was observed that apart from medical and nursing care other support facilities provided by the hospital like front office, also play a major role in customer satisfaction. Many activities are being processed through front office like discharge, registration, billing, report collection, enquiry and counseling. Patient can be highly dissatisfied by these services even though they are satisfied with actual medical care. Large percentages of respondents $(65.8 \%)$ were satisfied with the behavior of staff. According to them majority of the front office staff were courteous and polite. The remaining respondents who rated the staff as average or below average (needs improvement) think that there is a scope of improvement in professional efficiency of staff. $56.3 \%$ of the study population agree that the cleanliness is good. Rest rate it average or it needs improvement. Also, the seating arrangement $(58.9 \%)$, signage and directions $(72.8 \%)$, drinking water and washroom facilities $(51.9 \%)$ were also found to be good as per stated responses. Although, majority of the respondents agreed that other facilities like food, newspaper, mobile charging points are good but required in more numbers in order to cater high volume during peak hours.

Appointment system for taking doctor's appointment was recently introduced. Therefore, majority of the respondents were not familiar with the system (53.2\%). But, the patients who used the appointment system were mostly satisfied with it. But nearly $5.0 \%$ were not satisfied with the system because the patient who had the appointment for a particular time period could not see the doctor due to high backlog cases. The time spent by the patient on various activities were also analyzed and explained in the Graph 1.

To understand the role of various influencing factors on patient satisfaction at all, the selected front offices, correlation coefficient is calculated between various dependent and independent variables. The result of correlation is explained in the Table 1.

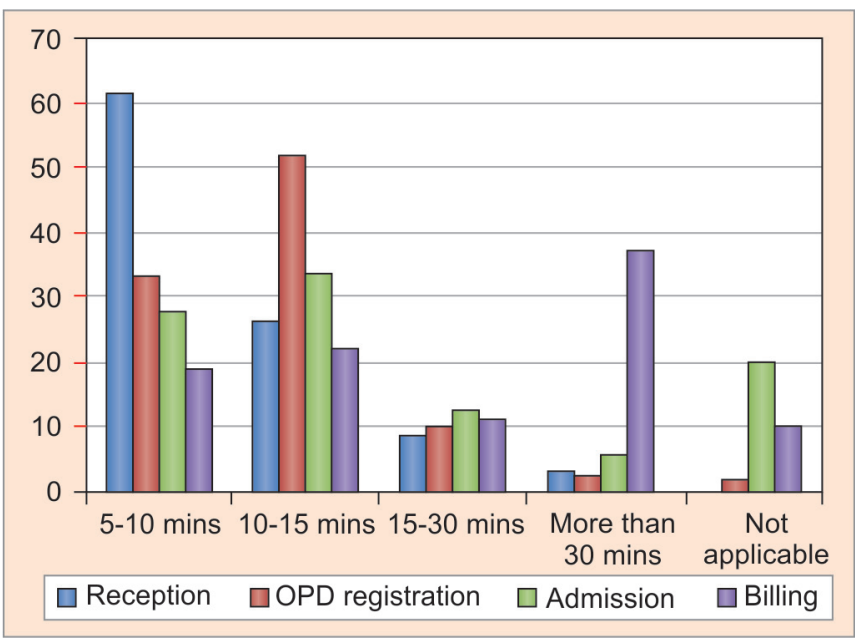

Graph 1: Time spent on different activities at the reception

From the Pearson correlation reported in Table 1 mentioned-above, Courteousness and Politeness is one of the main influencing factor and found to be highly correlated with different factors like TPA and corporate patients satisfaction level $(r=0.544, p<0.01)$, satisfaction with front office staff $(r=0.495, p<0.01)$ and overall satisfaction with the hospital $(r=0.602, p<0.01)$. Another independent variable, i.e cashless approval time is found to be highly correlated (negatively) with TPA and Corporate patients satisfaction level $(r=-0.785, p<0.01)$ and overall satisfaction level $(\mathrm{r}=0.522, \mathrm{p}<0.01)$. Approval time is also negatively correlated with overall satisfaction level $(r=-0.583, p<0.01)$. Seating arrangement $(r=0.332$, $\mathrm{p}<0.01)$ and availability of water and washroom facility $(r=0.388, p<0.01)$ is also correlated with satisfaction with front office staff.

\section{Employee Satisfaction and Its Influence on Patient Satisfaction}

The independent analysis of employee satisfaction revealed great deal of dissatisfaction among employees. Responses of employees on various satisfaction parameters are explained in Table 2. This shows that there was problem with almost every factor which was considered for measuring employee satisfaction. The employees are not at all happy with benefits program and expressed that organization is exploiting them. A large percentage of employees say that there is no clarity in the service rules defined by the organization. It was a general observation that the job description and job profile of the employees were not providing a clear picture of employee's duties and responsibilities. This further lead to overlapping of the functions of employees and they become multipurpose workers. Another problem was with the new employees who have joined the organization in last one year. There was no proper induction or training given while they joined the 
Role of Employee Satisfaction in Influencing Patient Satisfaction

\begin{tabular}{|c|c|c|c|c|c|c|c|}
\hline & $\begin{array}{l}\text { Courteous and } \\
\text { politeness }\end{array}$ & $\begin{array}{l}\text { TPA and } \\
\text { corporate } \\
\text { patients }\end{array}$ & Approval time & $\begin{array}{l}\text { Satisfaction } \\
\text { with front } \\
\text { office staff }\end{array}$ & $\begin{array}{l}\text { Water and } \\
\text { washroom } \\
\text { facility }\end{array}$ & $\begin{array}{l}\text { Seating } \\
\text { arrangements }\end{array}$ & $\begin{array}{l}\text { Overall } \\
\text { satisfaction }\end{array}$ \\
\hline Courteous and politeness & 1 & & & & & & \\
\hline TPA and corporate patients & $\begin{array}{l}0.544 \\
0.000\end{array}$ & 1 & & & & & \\
\hline Approval time & $\begin{array}{l}0.091 \\
0.256\end{array}$ & $\begin{array}{l}-0.785^{\star *} \\
0.000\end{array}$ & 1 & & & & \\
\hline $\begin{array}{l}\text { Satisfaction with front office } \\
\text { staff }\end{array}$ & $\begin{array}{l}0.495^{\star *} \\
0.000\end{array}$ & $\begin{array}{l}-0.025 \\
0.756\end{array}$ & $\begin{array}{l}-0.051 \\
0.523\end{array}$ & 1 & & & \\
\hline $\begin{array}{l}\text { Water and washroom } \\
\text { facility }\end{array}$ & $\begin{array}{l}0.296^{*} \\
0.000\end{array}$ & $\begin{array}{l}0.030 \\
0.704\end{array}$ & $\begin{array}{l}-0.016 \\
0.847\end{array}$ & $\begin{array}{l}0.388^{* *} \\
0.000\end{array}$ & 1 & & \\
\hline Seating arrangements & $\begin{array}{l}0.263^{*} \\
0.001\end{array}$ & $\begin{array}{l}0.113 \\
0.159\end{array}$ & $\begin{array}{l}0.068 \\
0.395\end{array}$ & $\begin{array}{l}0.332^{* *} \\
0.000\end{array}$ & $\begin{array}{l}0.386^{* *} \\
0.000\end{array}$ & 1 & \\
\hline Overall satisfaction & $\begin{array}{l}0.602 \\
0.000\end{array}$ & $\begin{array}{l}0.522^{* *} \\
0.000\end{array}$ & $\begin{array}{l}-0.583^{* *} \\
0.000\end{array}$ & $\begin{array}{l}0.143 \\
0.074 \\
\end{array}$ & $\begin{array}{l}-0.013 \\
0.871\end{array}$ & $\begin{array}{l}-0.138 \\
0.084\end{array}$ & 1 \\
\hline
\end{tabular}

Table 2: Employee's responses for various factors responsible for employee satisfaction

\begin{tabular}{lllllll}
\hline Components & $\begin{array}{l}\text { Strongly } \\
\text { agree }\end{array}$ & Agree & Disagree & $\begin{array}{l}\text { Strongly } \\
\text { disagree }\end{array}$ & $\begin{array}{l}\text { Not } \\
\text { applicable }\end{array}$ & $\begin{array}{c}\text { Total } \\
\text { Family friendly place }\end{array}$ \\
Clarity of service rules & 13.63 & 40.9 & 31.81 & 13.63 & 0 & 100 \\
Value of teamwork & 0 & 27.27 & 63.63 & 9.09 & 0 & 100 \\
Adequate orientation for new employees & 18.18 & 22.72 & 31.81 & 22.72 & 4.54 & 100 \\
Opportunity for improvization of skills & 4.54 & 36.36 & 54.54 & 9.09 & 0 & 100 \\
Usefulness of performance evaluation & 4.54 & 18.18 & 31.81 & 18.18 & 27.27 & 100 \\
Usefulness of total benefits programe & 0 & 31.81 & 9.09 & 9.09 & 45.45 & 100 \\
Friendliness and helpfulness by supervisor & 27.27 & 13.63 & 50 & 31.81 & 4.54 & 100 \\
Support for employee suggestions & 22.72 & 36.36 & 22.72 & 13.63 & 0 & 100 \\
Communication of info from management & 4.54 & 18.18 & 22.72 & 18.18 & 0 & 100 \\
Commitments to quality service & 0 & 31.81 & 59.09 & 9.09 & 0 & 100 \\
Value of individual employee & 4.54 & 22.72 & 40.9 & 27.27 & 4.54 & 100 \\
Fair treatment to employees & 9.09 & 27.27 & 36.36 & 27.27 & 0 & 100 \\
\hline
\end{tabular}

organization. They were also not informed or provided with clear job profile and responsibilities.

It is also surfaced that the informal training is the duty of the immediate supervisor and is given when a supervisor is asked for it. The front office employees of the hospital themselves believe that the organization is not committed to providing quality care to its customers. This was due to the fact that the employees themselves feel that they are being overloaded with the work and patients remain in the queue for hours in case of rush hours. All these above factors are responsible for these employees to feel that they are not properly looked after by the organization.

Various selected factors responsible for employee satisfaction and patient satisfaction were considered for correlation to understand the significance level. The result of the correlation is explained in the Table 3.

The correlation coefficient was calculated between factors of patient satisfaction and employee satisfaction. The result of correlation between overall patient satisfaction and satisfaction among TPA coordinators $(\mathrm{r}=0.522, \mathrm{p}<0.01)$ is very high, which shows that TPA coordinators are highly satisfied and providing good service to its customers. But, the correlation coefficient between overall patient satisfaction and value of individual employee in the organization $(\mathrm{r}=-0.437, \mathrm{p}<0.01)$ and fair treatment by employer $(\mathrm{r}=-0.465, \mathrm{p}<0.01)$ shows a high but negative value, that shows both these parameters are negatively correlated. In another response where employee's years of experience in current hospital was correlated with two important factors, i.e. family friendly atmosphere $(\mathrm{r}=-0.388, \mathrm{p}<0.01)$ and clear guidelines for promotion $(r=-0.602, p<0.01)$ also express negative relationship between these factors.

\section{CONCLUSION}

Previous studies have shown that patient satisfaction plays a key role in the health and future success of any healthcare service organization. When patients are satisfied, they keep coming back to the same organization for the services and also refer their friends to do the same. The organization should not forget to pay attention to employees needs - an action that is often overlooked in our competitive business 


\begin{tabular}{|c|c|c|c|c|c|c|}
\hline & $\begin{array}{l}\text { Satisfaction } \\
\text { of TPA } \\
\text { coordinators }\end{array}$ & $\begin{array}{l}\text { Satisfaction } \\
\text { of foreign } \\
\text { patients }\end{array}$ & $\begin{array}{l}\text { Front } \\
\text { office staff } \\
\text { satisfaction }\end{array}$ & $\begin{array}{l}\text { Value of } \\
\text { individual } \\
\text { employee }\end{array}$ & Fair treatment & $\begin{array}{l}\text { Overall patient } \\
\text { satisfaction }\end{array}$ \\
\hline Satisfaction of TPA coordinators & 1 & & & & & \\
\hline Satisfaction of foreign patients & $\begin{array}{l}-0.228^{* *} \\
0.004\end{array}$ & & & & & \\
\hline Front office staff satisfaction & $\begin{array}{l}-0.025 \\
0.756\end{array}$ & $\begin{array}{l}0.116 \\
0.146\end{array}$ & 1 & & & \\
\hline Value of individual employee & $\begin{array}{l}0.221^{* *} \\
0.005\end{array}$ & $\begin{array}{l}-0.138 \\
0.085\end{array}$ & $\begin{array}{l}-0.148 \\
0.064\end{array}$ & 1 & & \\
\hline Fair treatment & $\begin{array}{l}0.246^{* *} \\
0.002\end{array}$ & $\begin{array}{l}-0.140 \\
0.079\end{array}$ & $\begin{array}{l}-0.130 \\
0.104\end{array}$ & $\begin{array}{l}0.850^{* *} \\
0.000\end{array}$ & 1 & \\
\hline Overall patient satisfaction & $\begin{array}{l}-0.522^{* *} \\
0.000\end{array}$ & $\begin{array}{l}0.268^{* *} \\
0.001\end{array}$ & $\begin{array}{l}0.143 \\
0.074\end{array}$ & $\begin{array}{l}-0.437^{* *} \\
0.000\end{array}$ & $\begin{array}{l}-0.465^{\star *} \\
0.000\end{array}$ & 1 \\
\hline
\end{tabular}

environment. Organizations that attend to employee satisfaction can improve internal moral, prevent turnover, and enhance customer satisfaction.

In the study a number of major findings emerged from the outpatient satisfaction study. Patients were found to be satisfied with both the physical and behavioral dimensions of service and the overall patient satisfaction is high. The correlations between various factors were positively significant. At the same time employees were having some issues with the organization. This was further revealed in the correlation among various related factors. From the study it is clear that employees have some genuine issues with the organization but that is not reflecting while they deal with the patients and patients are satisfied with the front office staff to a great extent. From the literature it is also observed that in patient satisfaction study, which is the reluctance of patients to express their true feelings about the care they received, and also the 'generosity' factor as an intervening factor. Nonetheless, the outcome of the study cannot be ignored altogether despite the apprehensions.

\section{REFERENCES}

1. Available at: http://www2.uwstout.edu/content/lib/thesis/ 2005/2005willemss.pdf (accessed August 17,2012). Int J Multidis Resear 2011 December;1(8):.
2. Schlesinger L, Heskett J, Schlesinger Leonard A, James L, Heskett. Customer satisfaction is rooted in employee satisfaction. Haward Business Review 1991;69(6):148.

3. MacStravic S. Heath care's management myopia. Hospitals and Health Networks. Retrieved from www.hhnrnag.com.

4. MacStravic S. Treating the whole employee. Hospitals and Health Networks (2004). Retrieved from http://www.aqp.org.

5. Management Science Associates Inc. Feedback Leaders Workbook. Kansas City, MO: Management Science Associates Inc 2002.

6. Studor Q. Hardwiring Excellence. Gulf Breeze FL: Fire Starter Publishing. When to repeat the employee satisfaction survey (n.d.) 2003. Retrieved from: http://www.employeesurveys.com

7. Lee F. If Disney Ran Your Hospital 9 M Things You Would Do Differently. Bozeman MT: Second River Healthcare Press 2004.

8. Snyder R. What bad impressions say about organizations (Part II). Human Resource Quarterly 1998;9(2):179-185.

9. Bernardin H. Human Resource Management. 3rd ed. New York:McGraw-Hill Companies Inc; 2003.

10. Harris J, Brannick J. Finding and Keeping Great Employees. New York: AMA Publications 1999.

11. Kaye B, Jordan-Evans S. Love 'Em or Lose 'Em. San Francisco, CA: Berrett-Koehler Publishers Inc; 1999.

12. Lee B. Satisfaction Guaranteed. Calgary, Alberta, Canada: Mastery Publishing Company; 1996.

13. Lipson F. Health care's focus on the customer is in critical condition. The Journal for Quality and Participation $2000 \mathrm{March} /$ April: 27-28. Retrieved from: http://www.aqp.org. 